\title{
Efficacy of various pesticides against Red ant (Dorylusorientalis, Westwood) of potato
}

\author{
Nabadeep Saikia and Kapil Deb Nath* \\ Krishi Vigyan Kendra, Assam Agricultural University, Cachar- 788025 (Assam), INDIA \\ *Corresponding author. E-mail: kapildebnath88@gmail.com \\ Received: August 12, 2016; Revised received: June 13, 2017; Accepted: October 26, 2017
}

\begin{abstract}
Several management approaches against red ant of potato Dorylusorientalis (Westwood) were studied at farmer's field in Cachar district of Assam (India) during 2015-16 cropping season to find out the most effective management technique. Combination of Malathion 5\% dust @ $40 \mathrm{~kg}$ per hectare and Mustard Oil Cake (MOC) @ $150 \mathrm{~kg}$ per hectare reduced red ant damage significantly $(p \leq 0.05)$ followed by Dursben $20 \%$ EC @ 5 ml per litre and Carbofuran 3G@25 kg per hectare. Malathion and MOC was applied at the time of first earthing up gave the lowest infestation of red ant $(9.2 \%)$ and with $(64.31 \%)$ infestation reduction over control closely followed by Dursban $20 \%$ EC $(13.5 \%)$ and with $(59.32 \%)$ infestation reduction over control. Highest infestation $(47.6 \%)$ was recorded in the control untreated plot where; only chemical fertilizers were applied at recommended dose.
\end{abstract}

Keywords: Chloropyrifos, Dorylusorientalis, Malathion, MOC, Potato, Red Ant

\section{INTRODUCTION}

Potato (Solanum tuberosumL.) belongs to the family Solanaceae is used as the most important food for a large number of people in the world. It is the most important non-cereal food crop and ranks fourth in terms of total global food production after maize, wheat and rice (Chakraborty et al., 2000). Potato was introduced in the early part of $17^{\text {th }}$ century by the Portuguese. It was first cultivated in Surat on the West Coast. Now potato is established as the most important non cereal vegetable in India. In India, during 2012- 13, potato was grown in 1.99 mha of land with a production of 45.34 MT and yield recorded was $22760 \mathrm{~kg}$ per ha. India ranked $2^{\text {nd }}$ in production of potato after China in global potato production (FAOSTAT, 2015). India contributes around $12.33 \%$ of world potato production. Potato is one of the most important and popular vegetables in Assam also. It is used as main vegetable and represents about $50 \%$ of total edible vegetables. In Assam, potato is cultivated in 99.7 thousand hectare of land with production and productivity of 75.27 thousand tones and $9775 \mathrm{~kg}$ per hectare respectively (Anonymous, 2012). Potato crop is attacked by more than 80 numbers of insect pests from field to storage. Among several soil insects that attacks potato in the field, Red ants (Dorylusorientalis), is one of the most important soil pests of potato reducing the yield up to 35- 40\% in West Bengal (Konar et al., 2005). The pest made hole on the surface of tuber which reduced tuber yield as well as market quality (Butani et al., 1976). The insect is reported causing 70-90\% damage at harvest to potatoes in farmer's fields in Bihar (Ram et al.,
1993). Dorylusorientalis has long been known as an important pest of potato in middle and higher hills of Nepal (Gc et al.,1997) and it causes serious damage to potato, radish, carrot, cauliflower, cabbage and many solanaceous and cruciferous vegetables in Nepal (Joshi et al., 1998). It was reported that red ant severely damaged the marketable potato tuber yield in Nepal (Bhandari, 2011). Red ants are reported as a pest of potato, cauliflower, cabbage, groundnut, sugarcane, and coconut seedlings in the North-Eastern states, Bihar, and Uttar Pradesh (Roonwal, 1976). The pest appears during December and remains active until April, causing more than $10 \%$ of the damage in irrigated potato crops. High temperatures and dry weather favor population build-up (Kishore et al., 1990). The pest damages mainly the potato stems and tubers by chewing holes and in case of severe attack plants become wilt in direct sunlight and will eventually dry up (Trivedi and Rajagopal, 1999).

In Assam, Red ant is established to be a serious pest in all potato growing areas including the Cachar district. Tuber infestation in severe cases may be as high as 51.77- 61.50 per cent and recently it is reported as sporadic pest of French been in some places. Therefore, the present investigation was carried out to find out the suitable management approach for controlling potato red ant.

\section{MATERIALS AND METHODS}

The experiment was carried out at farmer's field near Krishi Vigyan Kendra, Cachar, Assam during 2015 -16 cropping season. Plot size was $6 \mathrm{~m} \times 6 \mathrm{~m}$ and raw to 
raw distance was maintained at $50 \mathrm{~cm}$ apart and plant distance at $20 \mathrm{~cm}$. All other agronomic practices are followed as per package of practice. The experiment was done in three replications in specific blocks. There were four treatments: T1, application of mustard oil cake@150kg/ha+Malathion5\%dust@40kg/ha. T2, Application of Dursban20 EC@5 ml per litre of water for 3 times. T3, application of Furadon3G@25 $\mathrm{kg} /$ ha for 3 times. T4, Untreated control where only chemical fertilizers were applied at recommended dose.

Combination of Mustard oil cake and malathion 5\% dust was applied at the time of first earthing up. During final harvest, data were taken on weight of healthy and infested tuber and per cent infestation was calculated using (Dash et al., 2013) the following formula:

$\%$ infestation $=$ Weight of infested potatoes $\times 100$ Total weight of potatoes

Yield data of different treatments were recorded to find out Benefit Cost Ratio using following formula:

$\mathrm{BCR}=$ Gross return $/$ Gross Cost

\section{RESULTS AND DISCUSSION}

From the study result indicated that one time application of the combination of Malathion 5\% dust@ @ 40 $\mathrm{kg}$ /ha and Mustard oil cake@150 kg /ha around the root zone at the time of first earthing up gave lowest tuber infestation (9.2\%). Efficient management of red ant by application of malathion 5\% dust and Mustard oil cake has also been described (Anonymous, 2009).

This was closely followed by three times application of Dursban20 EC@5ml/ltr of water around the root zone (13.5\%) applied three times at 10 days of interval from 45 DAS. Result of similar trend was also recorded by Dash et al., (2013). The highest infestation $(47.6 \%)$ was recorded from the control treatment.
(Table 1). During the cropping season highest red ant infestation reduction over control $(64.31 \%)$ was recorded from combination of Malathion 5\% dust and MOC followed by Dursban 20 EC (59.32\%). Highest yield was also obtained from application of combination of Malathion 5\% dust and MOC (19.5 ton/ha) closely followed by Dursban 20 EC (17.9 ton/ha). In terms of marketable yield, it can be concluded that highest marketable yield (17.71 ton/ha) was recorded in the T1, application of mustard oil cake @ $150 \mathrm{~kg} / \mathrm{ha}$ + Malathion 5\% dust@40 kg/ha, which was closely followed by T2, application of Dursban 20 EC @ 5 ml/ ltr of water (15.48 ton/ha). Lowest marketable yield was recorded from control treatment $(6.29$ ton). The highest benefit cost ratio (BCR) was recorded in the plot treated with combination of Malathion $5 \%$ dust and MOC followed by Dursban 20 EC treated and Carbafuron 3G (Table 2). Dash et al., 2013 found the highest MBCR 9.53 and 7.93 respectively by applying Kerosene@5 ml per litre of water and Dursban 20 EC (a) $5 \mathrm{ml}$ per litre of water.

\section{Conclusion}

From the experiment, it can be concluded that application of malathion 5\% dust @ 40 kg/ha along with Mustard oil cake (MOC)@150 kg/ha at the time of earthing up can manage the red ant infestation very efficiently. However, Dursban 20 EC applied @ 5ml/ltr of water for three times starting from 45 days after planting at 10 days interval also proved to be good which closely followed the Malathion 5\% dust and MOC combination.

\section{REFERENCES}

Anonymous. (2009). Tuber Crops, Potato. Package of Practices for Rabi Crops of Assam. Assam Agricultural

Table 1. Efficacy of different management practices on the infestation of red ant on potato during 2015-16. $(\mathrm{p} \leq 0.05)$.

\begin{tabular}{llll}
\hline Treatment & $\begin{array}{l}\text { \% Tuber infesta- } \\
\text { tion (by wt) }\end{array}$ & $\begin{array}{l}\text { \% Tuber infestation re- } \\
\text { duction over control }\end{array}$ & $\begin{array}{l}\text { Gross } \\
\text { (ton/ha) }\end{array}$ \\
\hline Maiathion5\% Dield \\
Dursban20EC (chloropyriphos) & 9.2 & 64.31 & 19.5 \\
Carbafuron 3G (Furadon) & 13.5 & 59.32 & 17.9 \\
Control (Use of only recommended dose of fertilizer) & 47.6 & 48.06 & 17.1 \\
\hline
\end{tabular}

Table 2. Economic analysis of different management practices against red ant on potato during 2015-16. $\mathrm{p} \leq 0.05$ ).

\begin{tabular}{|c|c|c|c|c|c|}
\hline Treatment & $\begin{array}{l}\text { Sound potato } \\
\text { Yield (QTL/ha) }\end{array}$ & $\begin{array}{l}\text { Additional yield over } \\
\text { control (QTL/ha) }\end{array}$ & $\begin{array}{l}\text { Gross return } \\
\text { Rs/Ha }\end{array}$ & $\begin{array}{l}\text { Gross cost } \\
\text { Rs/Ha }\end{array}$ & BCR \\
\hline Maiathion5\% Dust + Mustard oil cake & 177.06 & 114.18 & $2,65,590 /-$ & $97,650 /-$ & 2.72 \\
\hline Dursban20EC (chloropyriphos) & 154.83 & 91.95 & $2,32,245 /-$ & $91,200 /-$ & 2.54 \\
\hline Carbafuron 3G(Furadon) & 121.07 & 58.19 & $1,81,605 /-$ & $97,500 /-$ & 1.86 \\
\hline $\begin{array}{l}\text { Control (use of only recommended dose } \\
\text { of fertilizer) }\end{array}$ & 62.88 & -- & $94,320 /-$ & $90,000 /-$ & 1.05 \\
\hline
\end{tabular}


University, Jorhat and Department of Agriculture, Assam, pp 88-89.

Anonymous. (2012). Reports. Directorate of Economics and Statistics, Government of Assam, India.

Bhandari, M. R. (2011). Assessment of red ant organic management options in potato field of Dhading, Nepal. Nepalese Journal of Agricultural Sciences. 9: 90-94.

Butani, D. K. and Verma, S. (1976). Pest of vegetables and their control: sweet potato. Pesticides. 10(2): 36-38.

Chakraborty. S., Chakraborty, N. and Datta, A. (2000). Increased nutritive value of transgenic potato by expressing a non-allergenic seed albumin gene from Amaranthus hypochondrioccus. Proceeding of National Academy of Science USA. 97(7): 3724-3729.

Dash, C. K., Hassan,K., Pramanik, M. E. A., Rashid, M. H. and Choudhury, A. R. (2013). Development of management strategies against red ant (Dorylusorientalis, Westwood) of potato. Universal Journal of Plant Science. 1(3): 74-77.

FAOSTAT (2015).faostat.fao.org. Retrieved 25 January 2015

Gc, Y. D., Pandey, R. R. and Dhital, B. K. (1997). Management of red ant on potato and cauliflower during
1994/95 and 1995/96. Lumle Agricultural Research Centre, Kaski, Nepal LARC Working Paper No. 97/26.

Joshi, S. L. (1998). Ecology and Management of Red Ants in Nepal. PhD Thesis, Imperial College of Science, Technology and Medicine, Ascot, Berkshire, UK.

Kishore, R., Ram, G. and Misra, S. S. (1990). Red ant, Dorylusorientalis, Westwood-an insect pest of potatoes in Bihar. Journal of Entomological Research. 14(1): 8788

Konar, A., Paul,S.,Basu, A. and Chattri, M. (2005). Integrated management of mole cricket attacking potato in Eastern Gangclic plains of West Bengal. Potato Journal. 32: 3-4.

Ram, K., Misra, S. S. and Singh, L. (1993). Incidence of red ant. Dorylusorientalis on different genotypes. Journal of the Indian Potato Association. 20: 62

Roonwal, M. L. (1976). Plant pest status of root eating ants. Dorylusorientalis with notes on taxonomy, distribution and habits (Insects: Hymenoptera). Journal of Bombay Natural History Society. 72: 305-313.

Trivedi, Rajagopal, D. (1999). Integrated Pest Management in Potato. IPM System in Agriculture, Cash Crops. 6, pp 299-313. 